\title{
Novel bio-electro-Fenton technology for azo dye wastewater treatment using microbial reverse-electrodialysis electrolysis cell
}

\author{
Li, Xiaohu; Jin, Xiangdan; Zhao, Nannan; Angelidaki, Irini; Zhang, Yifeng
}

Published in:

Bioresource Technology

Link to article, DOI:

10.1016/j.biortech.2016.12.114

Publication date:

2017

Document Version

Peer reviewed version

Link back to DTU Orbit

Citation $(A P A)$ :

Li, X., Jin, X., Żhao, N., Angelidaki, I., \& Zhang, Y. (2017). Novel bio-electro-Fenton technology for azo dye wastewater treatment using microbial reverse-electrodialysis electrolysis cell. Bioresource Technology, 228, 322-329. https://doi.org/10.1016/j.biortech.2016.12.114

\section{General rights}

Copyright and moral rights for the publications made accessible in the public portal are retained by the authors and/or other copyright owners and it is a condition of accessing publications that users recognise and abide by the legal requirements associated with these rights.

- Users may download and print one copy of any publication from the public portal for the purpose of private study or research.

- You may not further distribute the material or use it for any profit-making activity or commercial gain

- You may freely distribute the URL identifying the publication in the public portal 
$1 \quad$ Novel bio-electro-Fenton technology for azo dye wastewater treatment using

2 microbial reverse-electrodialysis electrolysis cell

Denmark

6

$7 \quad *$ Corresponding author:

8 Dr. Yifeng Zhang

9 Department of Environmental Engineering, Technical University of Denmark, Denmark

Tel: (+45) 45251429.

Fax: (+45) 45933850.

E-mail address: yifz@env.dtu.dk

${ }^{\#}$ Both authors contributed equally to this work 


\section{Abstract}

Development of sustanaible technologies for treatment of recalcitrant pollutants containing wastewaters has long been of great interest. In this study, we proposed an innovative concept of using microbial reverse-electrodialysis electrolysis cell (MREC) based Fenton process to treat azo dye wastewater. In such MREC-Fenton integrated process, the production of $\mathrm{H}_{2} \mathrm{O}_{2}$ which is the key reactant of fenton-reaction was driven by the electrons harvested from the exoelectrogens and salinity-gradient between sea water and fresh water in MREC. Complete decolorization and mineralization of $400 \mathrm{mg} \mathrm{L}^{-1}$ Orange $\mathrm{G}$ was achieved with apparent first order rate constants of $1.15 \pm 0.06$ and $0.26 \pm 0.03 \mathrm{~h}^{-1}$, respectively. Furthermore, the initial concentration of orange $\mathrm{G}$, initial solution $\mathrm{pH}$, catholyte concentration, high and low concentration salt water flow rate and air flow rate were all found to significantly affect the dye degradation. This study provides an efficient and cost-effective system for the degradation of non-biodegradable pollutants.

Key words: Microbial Reverse-electrodialysis Electrolysis cell (MREC), Fenton reaction, Salinity gradient, Azo dye, Wastewater 


\section{Introduction}

Azo dyes are the most important synthetic dyes in textile industries. During textile coloration processing, approximately $10-15 \%$ of azo dyes are lost in the discharged effluents (Pearce, 2003; Solanki et al., 2013). Textile wastewaters if not efficiently treated would consititue a serious environmental issue for water pollution (Wang \& Bai, 2016). Most of azo dyes have complex structures and are toxic, which makes them difficult to be degraded by biological processes (Banerjee et al., 2015). Electro-Fenton reaction as one of typical advanced oxidation processes has been extensively studied as a promising and efficient method for treatment of dyes wastewater (Nidheesh \& Gandhimathi, 2012). The most important advantages of Electro-Fenton technology are high efficiency and mild operating conditions (Martinez-Huitle et al., 2015). However, there are still several shortcomings such as short lifetime of catalyst, costy electrode materials and high energy consumption (ranges from 87.7 to $275 \mathrm{kWh} \mathrm{kg} \mathrm{TOC}^{-1}$ ), which hinder the industrial application (Gao et al., 2015; Martinez-Huitle et al., 2015; Nidheesh \& Gandhimathi, 2012; Rosales et al., 2012).

More recently, bioelectrochemical systems (BES) such as microbial fuel cell (MFC) and microbial electrolysis cell (MEC) based Electro-Fenton systems have been demonstrated as promising alternative method to the traditional Electro-Fenton process for the degradation of azo dyes (Feng et al., 2010; Solanki et al., 2013; Zhang et al., 2015b). In such systems, the electrons used for $\mathrm{H}_{2} \mathrm{O}_{2}$ production at the cathode are fully or partly derived from organic wastes by bacteria in the anode. Thus, the catalyst cost and energy-consumption have been greatly reduced. The BES-Fenton process not only can remove the biodegradable organics in anode chamber, but also can remove the biorefractory pollutants in cathode chamber (Solanki et al., 2013; Xu et al., 2011; Zhuang et al., 2010). However, there are still several challenges 
which need to be addressed before field application. For example, high mineralization efficiency has been mainly achieved at low dye concentration $\left(\leq 100 \mathrm{mg} \mathrm{L}^{-1}\right)$ in the MFCFenton process due to the extreme low $\mathrm{H}_{2} \mathrm{O}_{2}$ production (Asghar et al., 2014; Fu et al., 2010). Comparatively, MEC-Fenton system could be more efficient due to much higher and faster $\mathrm{H}_{2} \mathrm{O}_{2}$ production (Zhang et al., 2015b). However, the requirement of external power supply for MEC may add the capital and operational costs and also complicate the whole system. Thus, there is a great research and practical interest to develop more economical and efficient BES-Fenton system for dye wastewater treatment.

Recently, a novel type of BES system called microbial reverse-electrodialysis electrolysis cell (MREC), which combines a reverse electrodialysis stack (RED) and MEC have been developed to drive $\mathrm{H}_{2}$ or $\mathrm{CH}_{4}$ generation (Kim \& Logan, 2011a; Luo et al., 2014). In our previous study, the MREC system has been demonstrated as one promising system to produce high concentration of $\mathrm{H}_{2} \mathrm{O}_{2}$ with low electrical energy consumption. Therefore, intergration of MREC and Fenton process could be an ideal technology to remove azo dye, which has never been previously reported.

In the present study, we developed one novel MREC-Fenton system for the treatment of wastewater containing Orange $\mathrm{G}$ which is a typical model azo dye used in dyeing the textile fabrics (Banerjee et al., 2015; Cai et al., 2016). The effects of main process paremeters such as the wastewater $\mathrm{pH}$, initial Orange $\mathrm{G}$ concentration, $\mathrm{HC}$ and $\mathrm{LC}$ flow rate, and air flow rate were investigated. Furthermore, its concentration on the system performance was also investigated. It is the first time that MREC-Fenton system was used to degrade azo dye wastewater. This new system may offer a potential platform technology for azo dye wastewater treatment. 


\section{Materials and Methods}

\subsection{Configuration and operation of MREC-Electro-Fenton system.}

The MREC consists of anode and cathode chamber which were separated by a RED stack (Fig.1). The anode and cathode chamber had a working volume of $50 \mathrm{~mL}(5 \mathrm{~cm} \times 5 \mathrm{~cm} \times 2$ $\mathrm{cm})$ separately. The anode was a carbon fibre brush $(5.0 \mathrm{~cm}$ diameter, $5.0 \mathrm{~cm}$ length, MillRose, USA), which was heated to $450{ }^{\circ} \mathrm{C}$ for $30 \mathrm{~min}$ in a muffle furnace before use (Zhang \& Angelidaki, 2015b). The anode was first enriched with biofilm in a MFC using domestic wastewater collected from primary clarifier (Lyngby Wastewater Treatment Plant, Copenhagen, Denmark) together with acetate sodium $(20 \mathrm{mM})$ as substrate (Zhang \& Angelidaki, 2015a), and then transferred into the anode chamber of MREC. The cathode was a graphite plate $(3 \mathrm{~cm} \times 3 \mathrm{~cm})$. In order to avoid anode substrate limitation on the system performance, the anode chamber was continuously fed with domestic wastewater amended with acetate sodium $\left(\sim 1.6 \mathrm{~g} \mathrm{COD} \mathrm{L}^{-1}\right)$ at $100 \mathrm{~mL} \mathrm{~d}^{-1}$. The cathode chamber was filled with 40 mL Orange G-containing synthetic wastewater and operated in batch mode. Air was bubbled into the catholyte continuously at the rate of $8 \mathrm{~mL} \mathrm{~min}^{-1}$ expect otherwise mentioned. $\mathrm{HC}$ and LC solutions was $35 \mathrm{~g} \mathrm{~L}^{-1}$ and $0.35 \mathrm{~g} \mathrm{~L}^{-1} \mathrm{NaCl}$, respectively. All experiments were carried out in duplicate at room temperature $\left(22 \pm 2^{\circ} \mathrm{C}\right)$.

\subsection{Analytical methods.}

The concentration of Orange G was determined by a UV-vis spectrophotometry (Spectronic 20D+, Thermo Scientific) at $478 \mathrm{~nm}$ (Banerjee et al., 2015). The mineralization rate of orange $\mathrm{G}$ in the wastewater during the degradation experiment was estimated through the analysis of total organic carbon (TOC) of the samples measured by shimadzu TOC 5000 A. The pH was 
measured using a pH meter (PHM 210 pH meter, Radiometer). Chemical oxygen demand (COD) was measured according to the Standard Method (A.W.W.A, 1998). The voltage across on the external resistor (10 $\Omega$ ) was monitored with 30 min intervals using a digital multimeter (model 2700, Keithley Instruments, Inc., Cleveland, OH, USA). Current density was calculated base on the surface area $(3 \mathrm{~cm} \times 3 \mathrm{~cm})$ of cathode. Coulomic efficiency $(\mathrm{CE})$ were calculated as previous reported (Kim \& Logan, 2011a).

The apparent decolorization rate constant $\left(K_{a p p}\right)$ and mineralization rate constant $\left(K_{T O C}\right)$ were determined according to Eq. 1 and Eq. 2

$$
\ln \frac{C_{0}}{C_{t}}=K_{a p p} t
$$

$$
\ln \frac{T O C_{0}}{T O C_{t}}=K_{T O C} t
$$

where $\mathrm{C}_{0}\left(\mathrm{mg} \mathrm{L}^{-1}\right)$ and $\mathrm{C}_{\mathrm{t}}\left(\mathrm{mg} \mathrm{L}^{-1}\right)$ are the Orange $\mathrm{G}$ concentrations at time 0 and reaction time $\mathrm{t}$, respectively. $\mathrm{TOC}_{0}\left(\mathrm{mg} \mathrm{L}^{-1}\right)$ and $\mathrm{TOC}_{\mathrm{t}}\left(\mathrm{mg} \mathrm{L}^{-1}\right)$ are the $\mathrm{TOC}$ concentrations at time 0 and reaction time $\mathrm{t}$, respectively.

The TOC removal and corresponding electrical energy consumption were evalutated to determine whether the MREC-Fenton process is economical. Electrical energy consumption in the MREC system was mainly due to the pumping system for supply of anolyte, high concentration (HC) and low concentration (LC) solution and the aeration of catholyte. The specific electrical energy consumption was calculated in terms of the removal of $1 \mathrm{~kg}$ of TOC from dye wastewater by the MREC-Fenton process $\left(\mathrm{kWh} \mathrm{kg}^{-1}\right)$ using Eq. 3 .

$$
\text { Energy consumption }=\frac{1000000 \mathrm{~W}}{T O C_{0} \times V_{0}-T O C_{t} \times V_{t}}
$$


where $\mathrm{W}(\mathrm{kWh})$ is the total electrical energy consumption, which was measured by a spar meter (Type NZR230, S.L. Energitekinik, Denmark). $V_{0}(L)$ and $V_{t}(L)$ are the volume of dye wastewater at time 0 and reaction time $t$, respectively.

\section{Results and discussion}

\subsection{System performance}

Fig. 2 shows the decolorization and minerlization of orange $G$ in the cathode of MRECFenton system with the initial Orange $\mathrm{G}$ concentration of $100 \mathrm{mg} \mathrm{L}^{-1}$. The decolorization efficiency of Orange $\mathrm{G}$ reached to about $70 \%$ within one hour, and $88 \%$ of Orange $\mathrm{G}$ was removed after 3 hours (Fig. 2A). Comparatively, the decoloriezation efficiency of $10 \%$ was observed after 5 hours under open circuit condition (control 1), which could be due to the absorption on the electrode material and the anion membrane (the side closed to the cathode chamber). The Orange $\mathrm{G}$ decolorization efficiency without air flow in cathode chamber (control 2) and without $\mathrm{Fe}^{2+}$ addition in catholyte (control 3) only reached about $32 \%$ and $45 \%$, respectively, after 5 hours. The minerlization of Orange G in terms of TOC removal showed similar trend as decoloration. As shown in Fig. 2B, the TOC removal efficiency could reach to $87 \%$ after $5 \mathrm{~h}$, which was only $16 \%$ and $13 \%$ in control 2 and 3 , respectively. The slight decolorization observed in control experiments could be due to the reduction of Orange $\mathrm{G}$ as electron acceptor at the cathode. This is supported by the observation that Orange $\mathrm{G}$ could be decomposed to colorless shorter organic molecules without dissolved $\mathrm{O}_{2}$ in control 2 and lack of the Fenton regent $\left(\mathrm{Fe}^{2+}\right)$ in control 3. Similar behaviour from other azo dyes (e.g., Orange 7 and Methylene Blue) have been previously observed in BES system (Li et al., 2016; Mu et al., 2009; Zhang et al., 2015a). On the other hand, the results also confirmed that the removal of Organge $G$ was mainly due to the Fenton reaction driven by the energy from 
anodic bacteria and salinity gradient (Luo et al., 2011). In addition, based on the experiment data the degradation kinetics of Orange G dye were studied, which showed that degradation of Orange $\mathrm{G}$ dye followd a first-order reaction (Fig. 2). The decolorization rate constant $\left(\mathrm{K}_{\mathrm{app}}\right)$ and mineralization rate constant $\left(\mathrm{K}_{\mathrm{TOC}}\right)$ were $1.22 \mathrm{~h}^{-1}$ and $0.46 \mathrm{~h}^{-1}$, respectively. In recent studies for oxidization of Methylene blue (a compound similar to Orange G dye) in MFCMEC-Fenton system, $\mathrm{K}_{\text {app }}$ of $0.43 \mathrm{~h}^{-1}$ and $\mathrm{K}_{\mathrm{TOC}}$ of $0.22 \mathrm{~h}^{-1}$ were reported, which were much lower than that observed in this study (Zhang et al., 2015b). Feng et al. (2010) also reported a first order removal reaction of Orange II with $\mathrm{K}_{\text {app }}$ of $0.212 \mathrm{~h}^{-1}$ and $\mathrm{K}_{\mathrm{TOC}}$ of $0.0827 \mathrm{~h}^{-1}$ in MFC-Fenton system. These results demonstrated that the MREC-Fenton system could be more efficient than other BES system for azo dye wastewater treatment.

\subsection{The effect of initial wastewater $\mathrm{pH}$ on the system performance}

Degradation performance of organic compounds by Electro-Fenton technologies are often found to be dependent on the wastewater $\mathrm{pH}$, and for different dyes in different degradation systems, the effect of wastewater $\mathrm{pH}$ was found to vary greatly. On the other hand, the actual dye wastwaters may have variable $\mathrm{pH}$ values. Therefore, the effect of initial $\mathrm{pH}$ on the Orange $\mathrm{G}$ wastewater degradation in the MREC-Fenton system was examined. As shown in Fig.S1 (Supplementary data), the decolorization and TOC removal were greatly affected by the initial $\mathrm{pH}$ of the wastewater. The increasing of initial $\mathrm{pH}$ from 2 to 7 caused a decrease in decolorization rate and TOC removal rate. The highest removal rate of Orange $G$ was found at pH $2\left(79 \pm 0.8 \mathrm{mg} \mathrm{L}^{-1} \mathrm{~h}^{-1}\right)$ in the first hour, and the maximum decolorization efficiency reached to $100 \%$ after $4 \mathrm{~h}$ reaction. The decolorization and TOC removal rate decreased with further increasing of the initial $\mathrm{pH}$ from 3 to 7 . For example, when the $\mathrm{pH}$ increased to above 4, the decolorization rate of Orange $\mathrm{G}$ started to decline. When the $\mathrm{pH}$ increased to above 7 
(Fig. S1) during the reaction, the decolorization process continued with a rate of $4.9 \pm 0.4 \mathrm{mg}$ $\mathrm{L}^{-1} \mathrm{~h}^{-1}$, which was much lower than $32 \mathrm{mg} \mathrm{L}^{-1} \mathrm{~h}^{-1}$ (average in 3 hours) at $\mathrm{pH} 2$. However, the TOC was not decreasing with the reaction time when the initial $\mathrm{pH}$ was above 4 . Moreover, the $\mathrm{pH}$ also increasing along the reaction time in all tests (Fig.S1). In general, the decolourization efficiency was higher than the TOC removal at all the tested initial $\mathrm{pH}$. That is because the azo bond could be first cleaved by hydroxyl radical, resulting in the formation of colorless shorter organic molecules. The results observed was in line with the conventional Fenton process for Orange $G$ degradation (Cai et al., 2016). Even though the acidic environment is benefitting the cleavage of the azo bond and mineralization of azo dye, initial $\mathrm{pH}$ lower than 2 may counteract generation of hydroxyl radical. Thus, $\mathrm{pH} 2$ was adopted for the following test, unless otherwise stated.

\subsection{Effect of initial Orange G concentration}

The performance of azo dyes removal by the BES-Fenton process is often found to be independent on the dye concentration (Asghar et al., 2014). In this section, the initial concentration of Orange $\mathrm{G}$ was varied from 100 to $500 \mathrm{mg} \mathrm{L}^{-1}$ to explore its impact on the system performance. The time course of Orange $G$ dye degradation is shown in Fig. 3. For initial Orange G concentrations of 100, 200, 300, and $400 \mathrm{mg} \mathrm{L}^{-1}$, the degradation efficiency after 6 h was about $100 \%$, while degradation efficiency of $94.4 \%$ was obtained at $500 \mathrm{mg}^{-1}$ (Fig.3A). However, the $K_{\text {app }}$ and $K_{T O C}$ decreased with the increasing of Orange $G$ concentration (Fig.3B). For example, the $\mathrm{K}_{\text {app }}$ of $1.15 \pm 0.04 \mathrm{~h}^{-1}$ and $\mathrm{K}_{\mathrm{TOC}}$ of $0.46 \pm 0.05 \mathrm{~h}^{-1}$ were observed at initial concentration of $100 \mathrm{mg} \mathrm{L}^{-1}$, while only $0.59 \pm 0.03 \mathrm{~h}^{-1}$ and $0.21 \pm$ $0.01 \mathrm{~h}^{-1}$ were obtained at $500 \mathrm{mg} \mathrm{L}^{-1}$. The behaviour was consistent with that observed in MEC-Fenton and classical Fenton process (Zhang et al., 2015b). 

(Fig.3C). Similar to electro-Fenton and photoelectro-Fenton processes, relatively higher

201

current density was benefical for the degradation of Orange G (Pereira et al., 2016). Interestingly, the current density decreased along with decolorization of Grange G wastewater. For example, the current density decreased from $1.73 \pm 0.04$ to $1.26 \pm 0.02 \mathrm{~A} \mathrm{~m}^{-2}$ with the reaction time at the initial Grange $\mathrm{G}$ concentration of $400 \mathrm{mg} \mathrm{L}^{-1}$. This observation was different with previous report in which the current density was stable at same initial methylene blue concentration in MEC-Fenton system (Zhang et al., 2015b). The higher concentration Orange G lead to higher current density, which could support the conclusion that the Orange $\mathrm{G}$ might also function as electron acceptor at the cathode. Moreover, we can hereby deduce that Orange $G$ might be a stronger electron acceptor than oxygen in the cathode chamber, which still needs to be clarified in future work.

\subsection{Effect of cathode electrolyte on degradation of Orange $G$.}

It was previously shown that the supporting electrolyte can affect the Electro-Fenton process (Bakheet et al., 2013; Pajootan et al., 2014). In addition, the current density achieved in the MREC can also be increased by enhancing the concentration of the cathode supporting electrolyte (Nam et al., 2012). It is therefore of great interest to evaluate the effects of the cathode supporting electrolyte $\left(\mathrm{Na}_{2} \mathrm{SO}_{4}\right)$ on Orange $\mathrm{G}$ removal. In this investgation, the initial concentration of Orange $\mathrm{G}$ was kept at $400 \mathrm{mg} \mathrm{L}^{-1}$, while the concentration of $\mathrm{NaSO}_{4}$ varied from $0,25,50,75$, to $100 \mathrm{mM}$. Parameters describing the treatment performance such as decolorization, minerlization and current density were shown in the Fig.4. No significant difference on the final decolorization and minerlization efficiency was observed (Fig.4A and 4B) which was consistent with that observed in other Electro-Fenton systems (Bakheet et al., 
2013). However, the $K_{a p p}$ and $K_{\text {TOC }}$ (the slopes of the inserted figure) increased with the increasing of $\mathrm{NaSO}_{4}$ concentration and reached maximum value at $50 \mathrm{mM} \mathrm{NaSO}{ }_{4}(0.86$ and

$\left.0.24 \mathrm{~h}^{-1}\right)$. However, there was no further increas when the catholyte concentration was higher than $50 \mathrm{mM}$. In comparison, the current density increased slightly with the increasing of the concentration of $\mathrm{NaSO}_{4}$ within the tested range (Fig.4C). This is probably because higher concentration of the catholyte could enhance the conductivity and thereby lowering the overall resistance (D’Angelo et al., 2015).

\subsection{Effect of $H C$ and $L C$ flow rate on the system performance.}

High flow rates of HC and LC solutions can improve the cell potential of MREC (Kim \& Logan, 2011b). However, increasing flow rates could also increase energy consumption on pumping the $\mathrm{HC}$ and LC solutions through the RED stack. The energy required for pumping is an important cost for the MREC operation. Thus there is a trade off between pumping and treatment performance. The optimal flow rates of $\mathrm{HC}$ and LC solutions were different for various MREC systems (D’Angelo et al., 2015; Kim \& Logan, 2011a; Watson et al., 2015). In this study, an increase in the flow rate of the $\mathrm{HC}$ and $\mathrm{LC}$ from 0.2 to $0.5 \mathrm{~mL} \mathrm{~min}^{-1}$ improved the decoloration and the mineralization rate (Fig. 5). Notably, there was no remarkable difference on degradation rate when the $\mathrm{HC}$ and $\mathrm{LC}$ flow rate was between 1.0 and $1.5 \mathrm{~mL}$ $\min ^{-1}$. The current density increased with the increasing of HC and LC flow rate (Fig. 5C), which implied that the increase of $\mathrm{HC}$ and LC flow rate were able to accelerate the cathode reaction. The behavior was consistent with that observed in the MRC for electrical power production (Kim \& Logan, 2011b). Therefore, pumping intensity could be used as a control for the degradation of azo dye in the MREC. On the other hand, the decoloration and the mineralization rate might not always be improved by increasing solution flow rates. It could 
245 be due to that the $\mathrm{HC}$ and LC flow rate was no longer the predominate limiting factor when it over a certain level (e.g., $1.0 \mathrm{~mL} \mathrm{~min}^{-1}$ in this study), since the electrical energy output in RED depends on the predominate resistance at a given HC and LC flow rate (Zhu et al., 2015). Considering both the Orange $\mathrm{G}$ degradation and energy consumption, the optimal flow rate was considered to be $0.5 \mathrm{~mL} \mathrm{~min}^{-1}$.

\subsection{Effect of air flow rate on the system performance.}

The effect of air flow rate on decolorization rate are shown in Fig. 6. As presented in Fig. 6,

252 it was clearly shown that the Orange G degradation rate was greatly affected by the air flow rate. The $\mathrm{K}_{\mathrm{app}}$ and $\mathrm{K}_{\mathrm{TOC}}$ increased with the air flow rate and reached the maximum value at 16 $\mathrm{mL} \min ^{-1}$. When the air flow rate was further increased to $32 \mathrm{~mL} \mathrm{~min}^{-1}$, no further increase in $\mathrm{K}_{\mathrm{app}}$ was observed, while $\mathrm{K}_{\mathrm{TOC}}$ decreased slightly. The observation indicates that both inadequate and excessive air supply could deteriorate the mineralization. Moreover, the

257 enhanced air flow rate could increase the current density (Fig. 6B), which was consistent with

258 what has been observed in Electro-Fenton processes (Tian et al., 2016). The air flow rate 259 could also affect the total electrical energy consumption. Thus, setting an optimum air flow rate may not only improve the $\mathrm{H}_{2} \mathrm{O}_{2}$ production but also reduce the operating cost of the system (Tian et al., 2016; Zhou et al., 2013).

\subsection{Columbic efficiency and energy consumption}

263 The coulombic efficiency (CE) was $15.56 \pm 0.76 \%$ at the air flow rate $16 \mathrm{~mL} \mathrm{~min}^{-1}$ and $\mathrm{HC}$ 264 and LC solution flow rate of $0.5 \mathrm{~mL} \mathrm{~min}^{-1}$, while the COD removal reached $81.16 \pm 1.85 \%$ in the anode fed with domestic wastewater. The low CE could be due to the oxidation of organic matter by the non-exoelectrogenic microorganisms from wastewater. The anolyte $\mathrm{pH}$ was 
maintained at 6.7-7.9, which exclude inhibition of anodic biofilm by non optimal $\mathrm{pH}$ (Kim \& Logan, 2011b).

269

270

Energy consumption is one of the major concerns for wastewater treatment using ElectroFenton technology, especially for recalcitrant pollutant degradation (Liu et al., 2015). In this MREC-Fenton process, the current density for Orange $G$ decolorization was in the range of 1.27-1.37 $\mathrm{A} \mathrm{m}^{-2}$ (Fig. 6B), which is much lower than that required by Electro-Fenton process (500 $\mathrm{A} \mathrm{m}^{-2}$ ) (Pereira et al., 2016). The MREC-Fenton process was driven by renewable energy derived from domestic wastewater and salinity gradient, which are abundant and relatively unlimited (Kim \& Logan, 2011a; Zhu et al., 2014). The costs of the MREC-Fenton system mainly includ capital and operating costs. The MREC capital costs are approx. $930 €$ $\mathrm{m}^{-3}$ (in Denmark) (Zhang \& Angelidaki, 2016). The operating costs mainly include reagent costs and energy consumption for pumping. The MREC-Fenton system required energy consumption of $25.93 \mathrm{kWh}\left(\mathrm{kg}\right.$ TOC) ${ }^{-1}$, which is much lower than for traditional ElectroFenton peocess treat Orange 7 with a cost of $865 \mathrm{kWh}(\mathrm{kg} \text { TOC })^{-1}$ (Xu et al., 2008). It was also much lower than that required by sequential Electro-Fenton process $(45.8 \mathrm{kWh}(\mathrm{kg}$ $\mathrm{TOC}^{-1}$ ) (Gao et al., 2015). However, our estimates were based on small laboratory-scale reactor and more accurate assessment is required. The above results suggest that the MRECFenton system could be a potentially cost-effective method for azo dye degradation.

\subsection{Practical significance and perspectives}

The results in this study demonstrated that the MREC-Fenton system was environmentfriendly, efficient and low-cost compared to conventional Electro-Fenton system. In this process, the MREC not only can treat domestic wastewater in anode chamber, but also degrade Orange $\mathrm{G}$ in cathode chamber. Compared to other bioelectro-Fenton system such as 
MFC and MEC, the MREC has its own merits. Firstly, the degradation rate was greatly improved by employing the RED stacks between the anode and cathode, compared to MFC. Secondly, unlike MEC based Fonton process, the electric energy was mainly produced by RED stack using the renewable salinity-gradient energy which replaced the electrical grid power source. Furthermore, salinity-gradient, as source of energy, is abundant, which could be regenerated using waste heat and thermolytic solutions or seawater and river water (Kim \& Logan, 2011a; Nam et al., 2012; Zhu et al., 2014). Thirdly, the energy consumption was only $25.93 \mathrm{kWh}(\mathrm{kg} \mathrm{TOC})^{-1}$ under optimal operation condition, indicating that the MREC is a lowcost biolectro-Fenton system with efficient mineralization. Though promising, more efforts should be made to accelerate the industrial application. First of all, this system has the potential to degrade many refractory compounds, so other nonbiodegradable and toxic pollutants such as nitrobenzene and phenol should be tested for their potential degradation by this system. Although the decalorisation rate was high, the TOC removal rate was low. For improving the TOC removal rate, development of a more cost-effective and efficient MREC reactor configuration is required. Moreover, the $\mathrm{CE}$ was relatively low which could probably be improved by process optimisation. Lastly, large scale system with continuous-flow operation should be tested in order to validate the technology at industrial scale conditions.

\section{Conclusions}

This study demonstrated that the MREC-Fenton system is an effective and environmentally friendly technology for azo dye wastewater treatment. In such system, Orange $\mathrm{G}\left(400 \mathrm{mg} \mathrm{L}^{-1}\right)$ was not only effectively degraded with first order kinetic constant of $1.15 \pm 0.06 \mathrm{~h}^{-1}$, but also highly mineralized with TOC removal efficiency of $99.6 \%$ and $\mathrm{K}_{\mathrm{TOC}}$ of $0.26 \pm 0.02 \mathrm{~h}^{-1}$ at $\mathrm{pH}$ 2. Notably the energy consumption was only $25.93 \mathrm{kWh}(\mathrm{kg} \mathrm{TOC})^{-1}$. This work provides a 
cost-effective method for azo dye degradation, which is also attractive and applicable for efficient degradation of recalcitrant pollutants.

\section{Acknowledgments}

The authors would like to acknowledge financial support from the China Scholarship Council and the technical assistance by Hector Gracia with analytical measurements. This research was supported financially by The Danish Council for Independent Research (DFF-133500142)

\section{References}

1. A.W.W.A. 1998. American Public Health Association, Water Pollution Control Federation, Standard Methods for the Examination of Water and Wastewater, nineteenth. American Public Health Association, Washington, DC.

2. Asghar, A., Abdul Raman, A.A., Daud, W.M.A.W., 2014. Recent advances, challenges and prospects ofin situproduction of hydrogen peroxide for textile wastewater treatment in microbial fuel cells. J. Chem. Technol. Biotechnol. 89(10), 1466-1480.

3. Bakheet, B., Yuan, S., Li, Z., Wang, H., Zuo, J., Komarneni, S., Wang, Y., 2013. Electroperoxone treatment of Orange II dye wastewater. Water Res. 47(16), 6234-6243.

4. Banerjee, S., Chattopadhyaya, M.C., Chandra Sharma, Y., 2015. Removal of an azo dye (Orange $\mathrm{G}$ ) from aqueous solution using modified sawdust. J. Water. Sanit. Hyg. De. 5(2), 235-242.

5. Cai, M., Su, J., Zhu, Y., Wei, X., Jin, M., Zhang, H., Dong, C., Wei, Z., 2016. Decolorization of azo dyes Orange $G$ using hydrodynamic cavitation coupled with heterogeneous Fenton process. Ultrason. Sonochem. 28, 302-310.

6. D’Angelo, A., Galia, A., Scialdone, O., 2015. Cathodic abatement of Cr(VI) in water by microbial reverse-electrodialysis cells. J. Electroanal. Chem. 748, 40-46.

7. Feng, C.H., Li, F.B., Mai, H.J., Li, X.Z., 2010. Bio-Electro-Fenton Process Driven by Microbial Fuel Cell for Wastewater Treatment. Environ. Sci. Technol. 44(5), 18751880. 
8. Fu, L., You, S.J., Zhang, G.Q., Yang, F.L., Fang, X.H., 2010. Degradation of azo dyes using in-situ Fenton reaction incorporated into $\mathrm{H}_{2} \mathrm{O}_{2}$-producing microbial fuel cell. Chem. Eng. J. 160(1), 164-169.

9. Gao, G., Zhang, Q., Hao, Z., Vecitis, C.D., 2015. Carbon nanotube membrane stack for flow-through sequential regenerative electro-Fenton. Environ. Sci. Technol. 49(4), 2375-83.

10. Kim, Y., Logan, B.E., 2011a. Hydrogen production from inexhaustible supplies of fresh and salt water using microbial reverse-electrodialysis electrolysis cells. Proc. Natl. Acad. Sci. 108(39), 16176-16181.

11. Kim, Y., Logan, B.E., 2011b. Microbial reverse electrodialysis cells for synergistically enhanced power production. Environ. Sci. Technol. 45(13), 5834-5839.

12. Li, N., An, J., Zhou, L., Li, T., Li, J., Feng, C., Wang, X., 2016. A novel carbon black graphite hybrid air-cathode for efficient hydrogen peroxide production in bioelectrochemical systems. J. Power Sources 306, 495-502.

13. Liu, Y., Chen, S., Quan, X., Yu, H., Zhao, H., Zhang, Y., 2015. Efficient Mineralization of Perfluorooctanoate by Electro-Fenton with $\mathrm{H} 2 \mathrm{O} 2$ Electro-generated on Hierarchically Porous Carbon. Environ. Sci. Technol. 49(22), 13528-13533.

14. Luo, X., Zhang, F., Liu, J., Zhang, X., Huang, X., Logan, B.E., 2014. Methane production in microbial reverse-electrodialysis methanogenesis cells (MRMCs) using thermolytic solutions. Environ. Sci. Technol. 48(15), 8911-8918.

15. Luo, Y., Zhang, R., Liu, G., Li, J., Qin, B., Li, M., Chen, S., 2011. Simultaneous degradation of refractory contaminants in both the anode and cathode chambers of the microbial fuel cell. Bioresour Technol. 102(4), 3827-3832.

16. Martinez-Huitle, C.A., Rodrigo, M.A., Sires, I., Scialdone, O., 2015. Single and Coupled Electrochemical Processes and Reactors for the Abatement of Organic Water Pollutants: A Critical Review. Chem. Rev. 115(24), 13362-13407.

17. Mu, Y., Rabaey, K., Rozendal, R.A., Yuan, Z., Keller, J., 2009. Decolorization of Azo Dyes in Bioelectrochemical Systems. Environ. Sci. Technol. 43, 5137-5143.

18. Nam, J.Y., Cusick, R.D., Kim, Y., Logan, B.E., 2012. Hydrogen generation in microbial reverse-electrodialysis electrolysis cells using a heat-regenerated salt solution. Environ. Sci. Technol. 46(9), 5240-5246. 
19. Nidheesh, P.V., Gandhimathi, R., 2012. Trends in electro-Fenton process for water and wastewater treatment: An overview. Desalination 299, 1-15.

20. Pajootan, E., Arami, M., Rahimdokht, M., 2014. Application of Carbon Nanotubes Coated Electrodes and Immobilized $\mathrm{TiO}_{2}$ for Dye Degradation in a Continuous Photocatalytic-Electro-Fenton Process. Ind. Eng. Chem. Res. 53(42), 16261-16269.

21. Pearce, C., 2003. The removal of colour from textile wastewater using whole bacterial cells: a review. Dyes Pigments 58(3), 179-196.

22. Pereira, G.F., El-Ghenymy, A., Thiam, A., Carlesi, C., Eguiluz, K.I.B., Salazar-Banda, G.R., Brillas, E., 2016. Effective removal of Orange-G azo dye from water by electroFenton and photoelectro-Fenton processes using a boron-doped diamond anode. Sep. Purif. Technol. 160, 145-151.

23. Rosales, E., Pazos, M., Sanroman, M.A., 2012. Advances in the Electro-Fenton Process for Remediation of Recalcitrant Organic Compounds. Chem. Eng. Technol. 35(4), 609-617.

24. Solanki, K., Subramanian, S., Basu, S., 2013. Microbial fuel cells for azo dye treatment with electricity generation: a review. Bioresour Technol. 131, 564-571.

25. Tian, J., Zhao, J., Olajuyin, A.M., Sharshar, M.M., Mu, T., Yang, M., Xing, J., 2016. Effective degradation of rhodamine B by electro-Fenton process, using ferromagnetic nanoparticles loaded on modified graphite felt electrode as reusable catalyst: in neutral pH condition and without external aeration. Environ. Sci. Pollut. Res. 23(15), 1547115482.

26. Wang, J., Bai, R., 2016. Formic acid enhanced effective degradation of methyl orange dye in aqueous solutions under UV-Vis irradiation. Water Res. 101, 103-113.

27. Watson, V.J., Hatzell, M., Logan, B.E., 2015. Hydrogen production from continuous flow, microbial reverse-electrodialysis electrolysis cells treating fermentation wastewater. Bioresour Technol. 195, 51-56.

28. Xu, L., Zhao, H., Shi, S., Zhang, G., Ni, J., 2008. Electrolytic treatment of Acid Orange 7 in aqueous solution using a three-dimensional electrode reactor. Dyes Pigments 77(1), 158-164.

29. Xu, N., Zhou, S., Yuan, Y., Qin, H., Zheng, Y., Shu, C., 2011. Coupling of anodic biooxidation and cathodic bioelectro-Fenton for enhanced swine wastewater treatment. Bioresour Technol. 102(17), 7777-7783. 
403

404

405

406

407

408

409

410

411

412

413

414

415

416

417

418

419

420

421

422

423

424

425

426

427

428

429

430

30. Zhang, B., Wang, Z., Zhou, X., Shi, C., Guo, H., Feng, C., 2015a. Electrochemical decolorization of methyl orange powered by bioelectricity from single-chamber microbial fuel cells. Bioresour Technol. 181, 360-362.

31. Zhang, Y., Angelidaki, I., 2015a. Bioelectrochemical recovery of waste-derived volatile fatty acids and production of hydrogen and alkali. Water Res. 81, 188-195.

32. Zhang, Y., Wang, Y., Angelidaki, I., 2015b. Alternate switching between microbial fuel cell and microbial electrolysis cell operation as a new method to control $\mathrm{H}_{2} \mathrm{O}_{2}$ level in Bioelectro-Fenton system. J. Power Sources 291, 108-116.

33. Zhang, Y., Angelidaki, I., 2016. Microbial Electrochemical Systems and Technologies: It Is Time To Report the Capital Costs. Environ. Sci. Technol. 50(11), 5432-5433.

34. Zhou, L., Zhou, M., Zhang, C., Jiang, Y., Bi, Z., Yang, J., 2013. Electro-Fenton degradation of p-nitrophenol using the anodized graphite felts. Chem. Eng. J. 233, 185-192.

35. Zhu, X., Hatzell, M.C., Logan, B.E., 2014. Microbial Reverse-Electrodialysis Electrolysis and Chemical-Production Cell for $\mathrm{H}_{2}$ Production and $\mathrm{CO}_{2}$ Sequestration. Environ. Sci. Technol. Lett. 1(4), 231-235.

36. Zhu, X., He, W., Logan, B.E., 2015. Reducing pumping energy by using different flow rates of high and low concentration solutions in reverse electrodialysis cells. J. Membrane Sci. 486, 215-221.

37. Zhuang, L., Zhou, S., Yuan, Y., Liu, M., Wang, Y., 2010. A novel bioelectro-Fenton system for coupling anodic COD removal with cathodic dye degradation. Chem. Eng. J. 163(1-2), 160-163. 


\section{Figure Captions}

432

433

434

435

436

437

438

439

440

441

442

443

444

445

446

447

448

449

450

Fig. 1. Schematic illustration of the MREC-Fenton reactor. LC: low concentration $\mathrm{NaCl}$ solution; AEM: anion exchange membrane; CEM: cation exchange membrane; HC: high concentration $\mathrm{NaCl}$ solution.

Fig. 2. The decolorization and mineralization of Orange G. Control 1, open circuit; Control 2, without air flow in cathode; Control 3, without $\mathrm{Fe}^{2+}$ addition in azo dye wastewater. MREC-F (MREC-Fenton) conditions: $\mathrm{Fe}^{2+}$ concentration of $10 \mathrm{mM}$, initial $\mathrm{pH} 3$, air flow rate of $8 \mathrm{~mL}$ $\min ^{-1}, \mathrm{HC}$ and LC flow rate of $0.5 \mathrm{~mL} \mathrm{~min}^{-1}$.

Fig. 3. The effect of initial Orange $G$ concentration on the degradation of Orange $G$ in the MREC. Operational conditions: initial $\mathrm{pH} 2, \mathrm{Fe}^{2+}$ of $10 \mathrm{mM}, \mathrm{HC}$ and LC flow rate of $0.5 \mathrm{~mL}$ $\min ^{-1}$, and air flow rate of $8 \mathrm{~mL} \mathrm{~min}^{-1}$.

Fig. 4. The effect of cathode electrolyte concentration $\left(\mathrm{Na}_{2} \mathrm{SO}_{4}\right)$ on the degradation of Orange $\mathrm{G}$ in the MREC. Conditions: Orange $\mathrm{G}$ concentration of $400 \mathrm{mg} \mathrm{L}^{-1}$, initial $\mathrm{pH} 2, \mathrm{HC}$ and LC solutions flow rate of $0.5 \mathrm{~mL} \mathrm{~min}^{-1}$, and air flow rate of $8 \mathrm{~mL} \mathrm{~min}{ }^{-1}$.

Fig. 5. The effect of solution flow rate on the Orange G degradation in the MREC. Conditions: Orange $\mathrm{G}$ concentration of $400 \mathrm{mg} \mathrm{L}^{-1}$, initial $\mathrm{pH} 2, \mathrm{Fe}^{2+}$ of $10 \mathrm{mM}, \mathrm{NaSO}_{4}$ concentration of

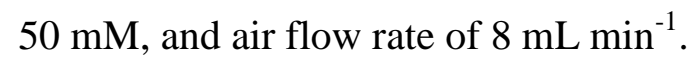

Fig. 6. The effect of air flow rate on the Orange $G$ degradation in the MREC. Conditions: Orange $\mathrm{G}$ concentration of $400 \mathrm{mg} \mathrm{L}{ }^{-1}$, initial $\mathrm{pH} 2, \mathrm{Fe}^{2+}$ of $10 \mathrm{mM}$, $\mathrm{HC}$ and $\mathrm{LC}$ solutions flow rate of $0.5 \mathrm{~mL} \mathrm{~min}^{-1}, \mathrm{NaSO}_{4}$ concentration of $50 \mathrm{mM}$. 
Figure 1

Click here to download Figure: Figure 1.docx

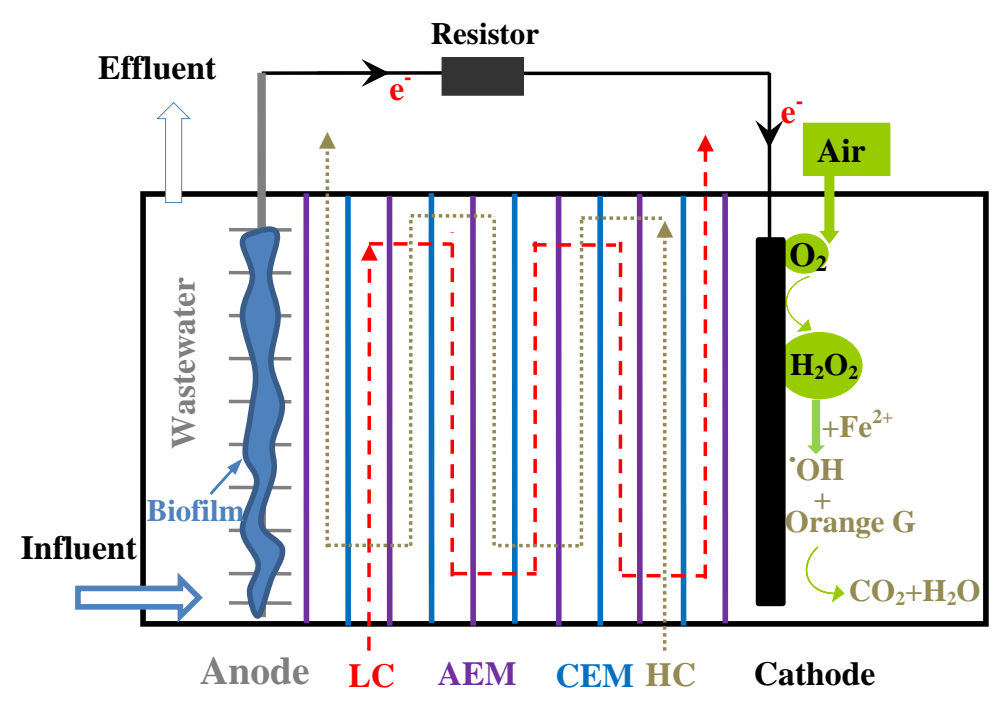

Fig. 1. 


\section{Figure 2}

Click here to download Figure: Figure 2.docx
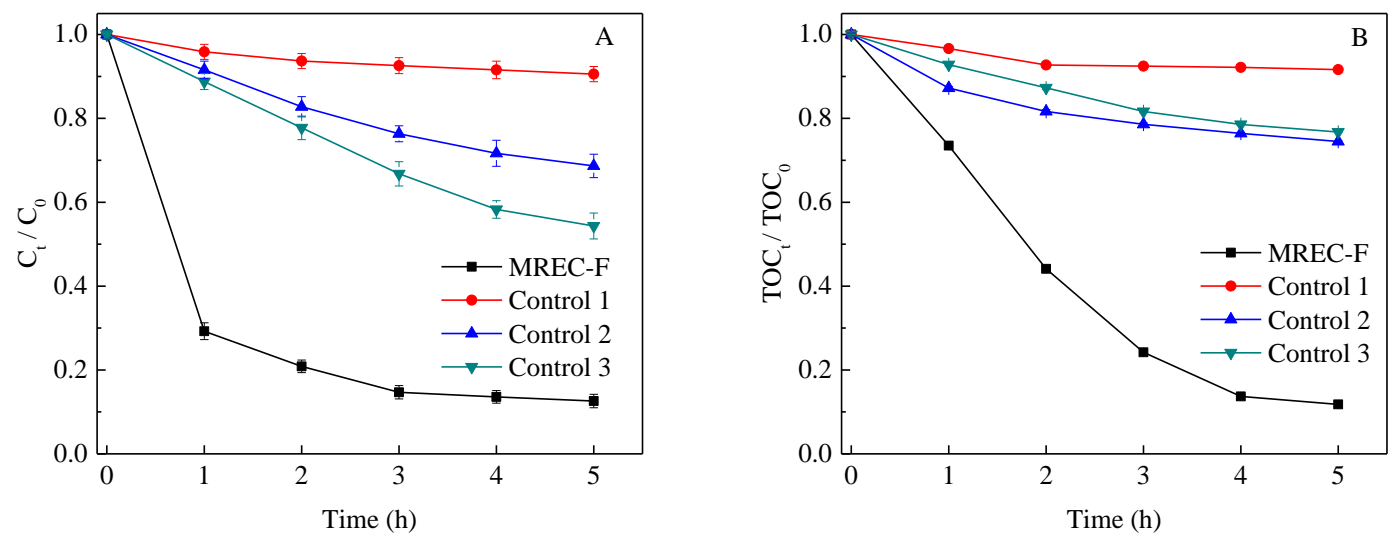

Fig. 2. 


\section{Figure 3}

Click here to download Figure: Figure 3.docx
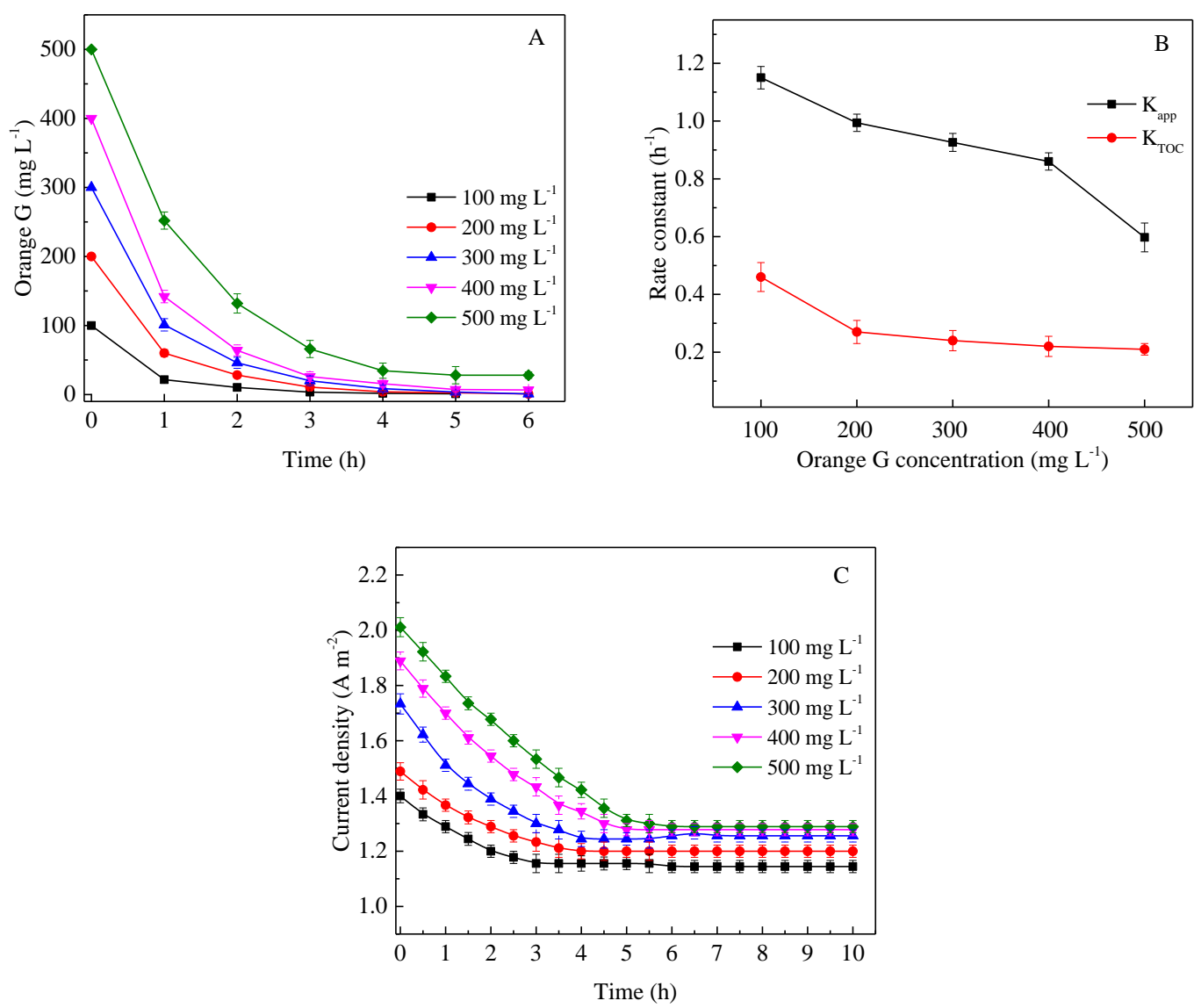

Fig. 3. 

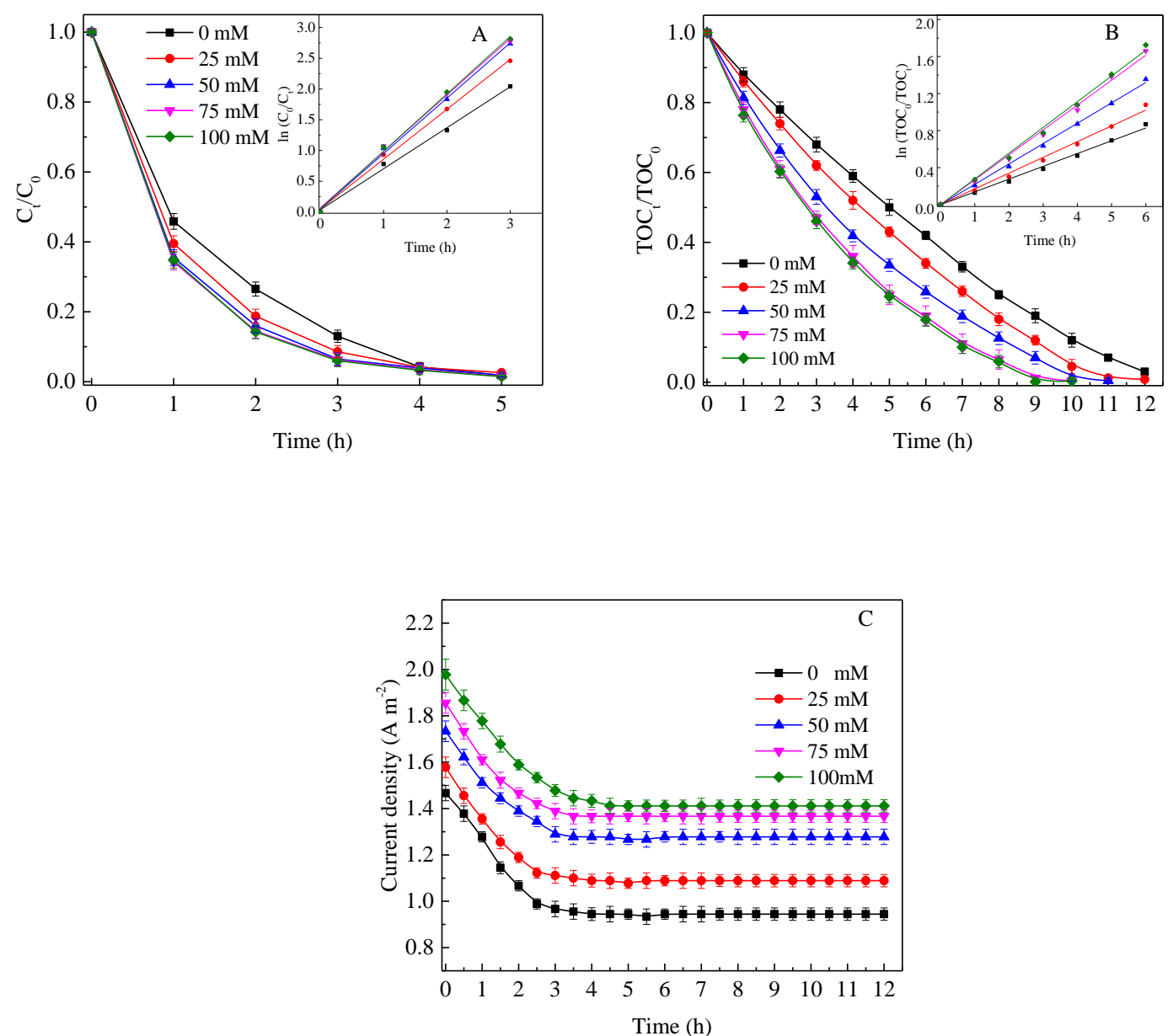

Fig. 4. 


\section{Figure 5}

Click here to download Figure: Figure 5.docx
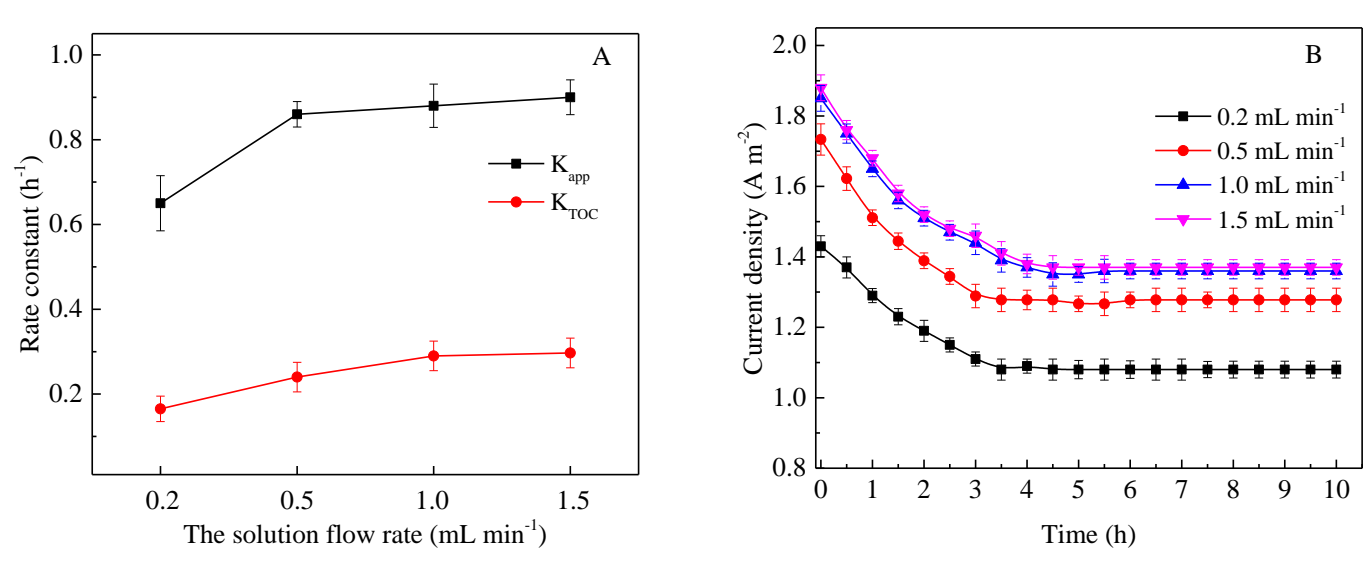

Fig. 5.

The solution flow rate $\left(\mathrm{mL} \mathrm{min}{ }^{-1}\right)$ 


\section{Figure 6}

Click here to download Figure: Figure 6.docx
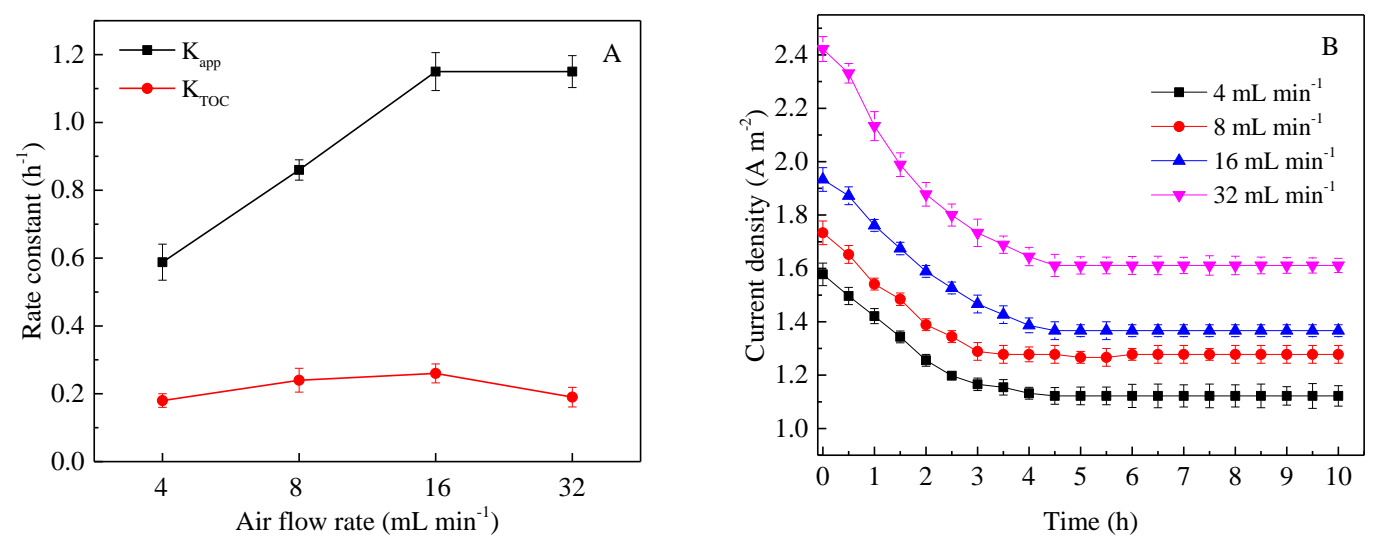

Fig. 6. 
Supplymentary data
Click here to download Electronic Annex: Supplementary data.docx 